\title{
The Challenge of SDG16.1 - Can We Halve Global Violence?
}

David Steven (Associate Director, Center on International Cooperation) Rachel Locke (Head of Research, SDG16.1, Center on International Cooperation)

Contents

I. From SDG16 to SDG16+

II. The Challenge of SDG16.1

III. SDG16.1 and the Prevention of Violent Conflict

IV. SDG16.1 and the Prevention of Non-Conflict Violence

V. Conclusion: Could We Halve Global Violence?

References 


\section{Abstract}

SDG16+ includes 36 targets from eight Sustainable Development Goals (here in after referred to as SDGs) that aim to build more peaceful, just and inclusive societies. While the SDG16+ targets apply to all countries, they draw attention to the needs of people, communities, and societies at greatest risk of being left behind due to violence, injustice, exclusion, and poor governance. SDG16.1 promises to significantly reduce all forms of violence everywhere. While the number of violent deaths will increase by 10\% by 2030 on current trends, the evidence suggests that conflict and non-conflict violence can be successfully prevented. Urgent action is needed to reduce the risk of conflict and to focus prevention on violence hotspots in cities. Longer-term efforts will transform harmful gender norms and make societies safer for women, children, and young people to live in. Those working on the prevention of different forms of violence should unite behind a common effort to implement SDG16.1.

Keywords: SDG16.1, SDG16+, Reduce Violence, Peaceful, Just and Inclusive Societies 


\section{I . From SDG16 to SDG16+}

Through the 2030 Agenda for Sustainable Development, the world's leaders made

a commitment to fostering "peaceful, just and inclusive societies which are free from fear and violence (UN, 2015).”

The Sustainable Development Goals (here in after referred to as SDGs) contain a series of ambitious targets for preventing violence in all its forms. They aim to promote the rule of law and provide justice for all, and to build transparent, effective and accountable institutions. The agenda also pledges to tackle inequality and exclusion, corruption, illicit financial and arms flows, and other factors that give rise to violence and insecurity.

The SDG16 is the main goal for building peaceful, just and inclusive societies, but the 2030 Agenda's negotiators placed related targets in other goals (Center on International Cooperation, unpublished). In all, 36 targets from eight SDGs directly measure an aspect of peace, justice, or inclusion. The SDG16+ $(<$ Figure $1>)$ brings together targets for various forms of violence, with a commitment to promoting safe environments for people to live in and a culture of peace and non-violence. It offers a perspective of a 'just society' that is based on human rights and gender equality. It brings together targets for governance with those for social, economic, and political inclusion.

The SDG16+ targets underpin the delivery of all parts of the 2030 Agenda. But the relationship also runs the other way. Factors from other SDGs reduce risk and increase resilience in ways that contribute to peace, justice and inclusion (Pathfinders for Peaceful, Just and Inclusive Societies, 2017: 15). This is line with the 2030 Agenda's affirmation that "there can be no sustainable development without peace and no peace without sustainable development (UN, 2015).”

The need for peace is greatest in the countries facing the highest levels of violence. The 2030 Agenda recognizes the urgency of the challenges facing the most vulnerable countries, including countries affected by conflict and post-conflict 
countries. These countries faced the highest obstacles to meeting the Millennium Development Goals (here in after referred to as MDGs; OECD, 2015). On current trends, between 43 and 60\% of the extreme poor will live in countries affected by conflict, violence, and fragility in 2030 (World Bank, 2018).

\section{〈Figure 1〉 SDG16+ Targets}

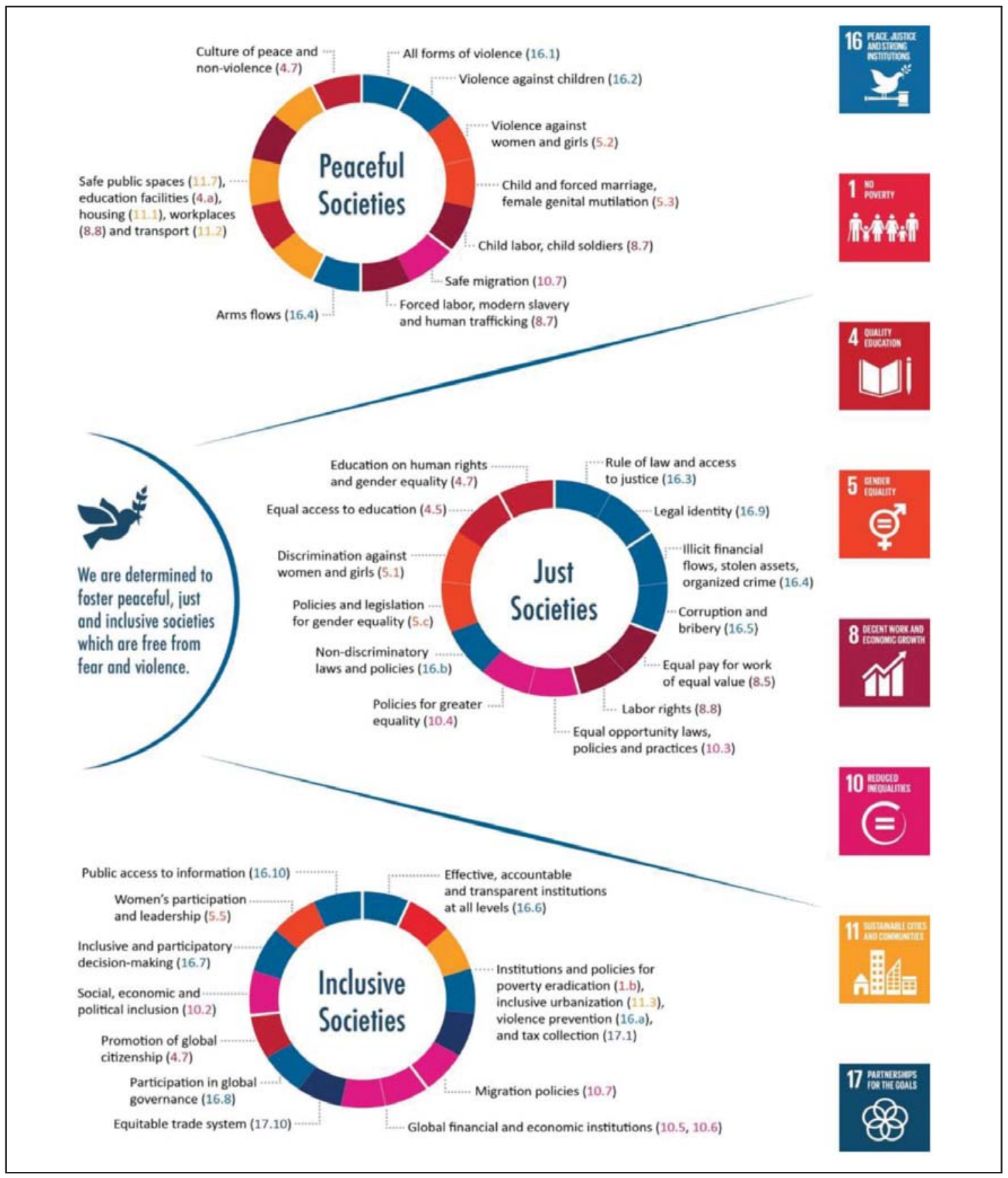

Source: Pathfinders for Peaceful, Just and Inclusive Societies (2017: 4) 
While universal in scope, the SDG16+ targets draw attention to the needs of people, communities, and societies that face the greatest risk of being left behind due to violence, injustice, exclusion, and poor governance (Pathfinders for Peaceful, Just and Inclusive Societies, 2017: 12). This provides a link to the Sustaining Peace resolutions, adopted by both the UN General Assembly and the Security Council, which underline that "development, peace and security, and human rights are interlinked and mutually reinforcing (UN, 2018)."

Through the Sustaining Peace resolutions, member states have called for action to prevent the "outbreak, escalation, continuation and recurrence of conflict (UN, 2018)," with the aim of helping a society move towards recovery, reconstruction, and development. The SDG16+ targets provide a guide for this action. Targeted and inclusive prevention strategies are needed where levels of violence are highest, reducing risks of conflict and providing foundations for more resilient and sustainable development.

At the same time, the universality of the SDG16+ targets must not be forgotten. All societies experience violence, injustice, and exclusion, with the burden falling disproportionately on disadvantaged people, groups, and communities. Democracy is under threat in many parts of the world ( $\mathrm{V}$-Dem Institute, 2018). Trust in governments and institutions is at an all-time low in many parts of the world (Open Government Partnership, 2018). All countries must strive to build more peaceful, just and inclusive societies. Through collective action, they must work together to reduce risks to peace that span national borders. 


\section{The Challenge of SDG16.1}

The Pathfinders for Peaceful, Just and Inclusive Societies (2017) - a multistakeholder but member state-led partnership - has developed a roadmap for implementation of these targets $(<\operatorname{Box} 1>)$. This was published during the high-level week of the UN General Assembly in September 2017.

In the roadmap, the Pathfinders underline the importance of SDG16.1, which makes a commitment to "significantly reduce all forms of violence and related death rates everywhere." SDG16.1 is backed up by targets for ending violence against women and children, and for tackling specific forms of violence and abuses such as modern slavery or child marriage.

〈Box 1〉 The Pathfinders for Peaceful, Just and Inclusive Societies

The Pathfinders for Peaceful, Just and Inclusive Societies brings together over 40 member states, international organizations, global partnerships and other parts to accelerate delivery the SDG16+ targets.

The Roadmap for Peaceful, Just and Inclusive Societies identifies strategies, actions, and enablers for the implementation of SDG16+. The transformative strategies cover the prevention of all forms of violence, institutional renewal to underpin sustainable development, and action to increase social, economic and political inclusion.

As an 'action platform', the Pathfinders are working to support national, regional, and international pathfinders as they make and implement commitments on SDG16+. The Pathfinders hosts a ministerial Task Force on Justice. It is developing new strategies for tackling inequality and exclusion, and is exploring the creation of an agenda for action on SDG16.1.

Source: Pathfinders for Peaceful, Just and Inclusive Societies (2017)

Conflict and non-conflict violence are a pervasive part of the lives of the many of the world's citizens. More than half a million people are killed violently each year and many more suffer physical injuries (McEvoy and Hideg, 2017). Beyond the direct consequences of violence lie a "wide spectrum of negative behavioral, cognitive, mental health, sexual and reproductive health problems, chronic diseases and social effects that arise from exposure to violence (WHO, 2014).” 
On current trends, SDG16.1 will not be met. According to a business-as-usual scenario, violent deaths will increase by nearly 10\% from current levels, reaching 610,000 deaths in 2030 (McEvoy and Hideg, 2017). Under this scenario, the number of conflict and non-conflict deaths would grow, although the homicide rate would decline slightly. A more negative scenario is also possible, if conflict deaths continue to rise and homicide rates regress towards the worst performers in each region. Under this scenario, violent deaths would grow to 819,000 in 2030, an increase of $46 \%$.

Under the business-as-usual scenario (and even more so under the negative scenario), high levels of violence and insecurity threaten the achievement of all 17 SDGs. But this path is not inevitable. Recent years have seen a substantial investment in understanding how to prevent violence, with an expert consensus that rapid reductions can often be achieved with sufficient commitment and resources (Bellis, Hardcastle, Hughes, Wood, and Nurse, 2017).

There are clear signs of a shift to prevention. The Secretary-General has called for prevention to permeate everything the United Nations (here in after referred to as UN, 2017) does. The UN and World Bank (2018) have united behind "Pathways for Peace," a shared framework for the prevention of violent conflict. The World Health Organization (WHO) has found governments are beginning to invest in the prevention of interpersonal violence (although "not on a scale that matches the burden”) (UN and World Bank, 2018).

New partnerships have recently been launched, including the Global Partnership to End Violence Against Children, the EU-UN Spotlight Initiative to eliminate violence against women and girls, and Alliance 8.7 (focusing on modern slavery and child labor). In Africa, Agenda 2063 aims to “silence the guns by 2020", while preventing violence against women and children (The African Union Commission, 2015). Latin America's Instinto de Vida campaign has set the challenge of halving lethal violence in ten years1).

1) Igarapé Institute, “Instinto de Vida,” Igarapé Institute’s website. available at https://igarape.org.br/en/ issues/citizen-security/instinto-de-vida/ (accessed on November 19, 2018). 
SDG16.1 has the potential to unite these disparate efforts behind a common mission, with the aim of achieving the significant and measurable decreases in violence by 2030. Linked to a broader effort to provide justice for all and promote inclusion, this will underpin progress towards more sustainable development in all countries, with greatest benefits for the people, communities, and countries at greatest risk of being left behind. 


\section{SDG16.1 and the Prevention of Violent Conflict}

Covering all forms of violence everywhere, SDG16.1 does not distinguish between conflict and non-conflict violence. led to a substantial and long-lasting increase in infant mortality. Between three from conflict (Wagner, Heft-Neal, Bhutta, Black, Burke, and Bendavid, 2018: 857-865). Indirect deaths result from the collapse of basic services in the short-term and from a longer-lasting "destructive impact on the national economy and infrastructure (including health facilities), on social cohesion, and on psychological health and well-being (Geneva Declaration on Armed Violence and Development, 2008)." Today over 68.5 billion people are displaced from their homes, the majority due to violence and conflict2).

Recent years have seen "a surge and expansion" of violent conflict, with more countries experiencing conflict than at any time in the past 30 years (UN and World Bank, 2018: 11). According to "Pathways for Peace," this growth is driven by three factors: the wave of violence that followed the Arab Spring, the spread of violent extremism and the growth of non-state conflict actors, and competition for power in African countries that are undergoing rapid demographic, social, economic, and increasingly environmental change.

Wars are not isolated from other forms of violence. Conflict, violent extremism, and criminal violence are interlinked and reinforce each other (UN and World Bank, 2018). Human rights abuses act as an early-warning signal for violent conflict, increase during conflict, and create further conflict risks (World Bank, 2011). Conflict increases women's exposure to other forms of violence (OECD, 2017), while genderbased violence is another early-warning signal (OSCE/ODIHR, 2009). Children face

2) UNHCR, “Global Trends Forced Displacement in 2017,” UNHCR, the UN Refugee Agency website, available at http://www.unhcr.org/globaltrends 2017/ (accessed on November 19, 2018). 
large--scale abductions, recruitment into armed groups, sexual violence, and other forms of abuse (Office of the Special Representative of the Secretary-General for Children and Armed Conflict, 2018). Individual exposure to violence has lifelong effects, including a greater risk of repeat victimization and of becoming a perpetrator of violence (Know Violence in Childhood, 2017). For societies, conflict "paves the way for higher tolerance of interpersonal violence, increased weapons and drug trade, and political corruption (OECD, 2016).”

Despite these adverse trends, the Pathways report argues that prevention reduces the risks of conflict and is cost effective. It identifies the need for an increased focus on prevention along a continuum that runs from environments where risks are emerging or where they have reached critical levels, to contexts of open violence or where violence has halted and avoiding recurrence is a priority (UN and World Bank, 2018: 99-100). At each of these stages:

Prevention is a process of building systems where actors are more likely to choose peaceful pathways, by taking advantage of favorable structural factors or mitigating the impacts of unfavorable ones, building incentive structures that encourage peace, and containing violence when it does occur. (UN and World Bank, 2018: 100)

The Pathways framework is aligned with the SDG16+ targets. A reduction in acute levels of violence provides an opening for societies to develop more sustainably. Justice systems must be equipped to manage conflicts without violence in arenas such as land, natural resources, and service delivery. Strengthened institutions are needed to mediate imbalances of power and rebuild trust within a society. More inclusive approaches to prevention can help respond to long-standing patterns of exclusion, reducing grievances and rebuilding a community's stake in a peaceful, shared future. 


\section{SDG16.1 and the Prevention of Non-Conflict Violence}

The risk of non-conflict violence is unevenly distributed. Fewer than half of the

world's 20 most violent countries are affected by conflict, reflecting extremely high levels of non-conflict violence, especially in urban centers (Small Arms Survey, 2016). High-income countries have seen much faster declines in their murder rates than those with middle and low incomes (WHO, 2014). As a result, the group of countries with low homicide rates is growing and is now home to more than four billion people. Just 10\% of the global population, or around 700 million people, live in countries with the highest homicide levels (Small Arms Survey, 2015).

Women, children, and young men are most vulnerable to violence. Over a third of women have experienced physical or sexual violence at the hands of their partners, or have been victims of non-partner sexual violence (WHO, London School of Hygiene \& Tropical Medicine, and South African Medical Research Council, 2013). One billion children are victims of serious violence each year (Hillis, Mercy, Amobi, and Kress, 2016). 700 million women were married before the age of 18, and 250 million before the age of 15 (UNICEF, 2014). More than 125 million girls and women have been victims of female genital mutilation (FGM) in 29 countries where the practice is most prevalent (UNICEF, 2013). About one in ten children aged 5-17 years are child laborers (Diallo, Etienne, and Mehran, 2013). Young men are disproportionately likely to be victims (and perpetrators) of many forms of violence, with homicide the fourth leading cause of death for young people globally (WHO, 2015).

There is a consensus that significant reductions in these forms of violence can be achieved. The first Global Violence Reduction Conference concluded that, for interpersonal violence, "a global'. reduction by 50\% in the next 30 years is achievable if policy makers harness the power of scientific evidence on violence reduction (Krisch, Eisner, Mikton, and Butchart, 2015).” The Igarapé Institute and Inter-American Development Bank have made a similar argument for Latin America, arguing that a 50\% decline in violence could be achieved in just ten years (Muggah 
and Alvarado, 2016). Based on the track record of 25 countries that saw at least a 30\% decline in homicide rates between 2000 and 2012, the Organization for Economic Cooperation (here in after referred to as OECD) argues that a rapid decline in violence is possible, although it underlines that while "halving the murder rate in any one of the countries most affected by violence is within historical precedent, to do so in most of them is not (OECD, 2015)."

Recent efforts have focused on helping policymakers understand how to use evidence to support violence prevention. "The Global Status Report on Violence Prevention" identifies six 'best buy' strategies for preventing interpersonal violence at a policy and programmatic level (WHO, 2014: 47). A group of international organizations 3 ) have proposed a framework to underpin action to prevent violence against women in 2015 (UN Women, 2015). For children, a similar group4) identified the seven INSPIRE strategies for ending violence against children (WHO, CDC, End Violence Against Children, PAHO, PEPFAR, Together for Girls, UNICEF, UNODC, USAID, and World Bank, 2016: 75). These multi-sectoral approaches to prevention are based on data about the scope of the problem, identification of risk and protective factors, implementation of evidence-based interventions, and monitoring of impacts and cost-effectiveness 5$)$.

Researchers have also identified evidence-based effective strategies for targeting violence hotspots in urban areas (Weisburd, Farrington, and Gill, 2016). The worst affected cities can achieve rapid reductions in violence through "proactive engagement with the police and other civic partners to enhance legitimacy and build social cohesion (Weisburd et al., 2016: 313)." In some cases, the fall in youth homicides has exceeded 50\% (Braga and Weisburd, 2012). Given that non-conflict lethal violence is typically concentrated within a small number of city neighborhoods, this demonstrates clear potential for accelerating progress on SDG16.1 (Krisch et al., 2014).

3) UN Women, ILO, UNDP, UNESCO, UNFPA, UNOHCHR, WHO

4) WHO, CDC, End Violence Against Children, PAHO, PEPFAR, Together for Girls, UNICEF, UNODC, USAID, and World Bank

5) Violence Prevention Alliance, "The Public Health Approach," available at http://www.who.int/violen ceprevention/approach/public_health/en/. 


\section{Conclusion: Can We Halve Global Violence?}

SDG16+ provides a framework for building more peaceful, just and inclusive societies. SDG16.1 calls for urgent action to achieve significant and quantified reductions in violence. This target is yet to command sufficient attention, but it must do so in the early 2020s if the SDGs are to be successfully implemented. Just as halving poverty inspired those working on the MDGs, an objective to halve global violence could become central to the 2030 Agenda.

Three obstacles inhibit greater action on SDG16.1. First, advocacy focuses primarily on problems, rather than solutions, feeding fatalism and obscuring the evidence that violence can be prevented. Second, resources flow into ineffective and often unbalanced in their support for coercive approaches rather than towards inclusive prevention strategies that have the greatest potential to build more peaceful societies (UN and World Bank, 2015). Third, there is no single point of ownership for reducing all forms of violence everywhere within the international system, leading to a fragmentation between communities working to prevent different forms of violence.

Immediate priorities are to build political will by convincing decision makers that violence is a preventable epidemic. Partners who work on different forms of violence - both conflict and non-conflict - should unite around a compelling vision for how rapid reductions in violence can most rapidly be achieved. At sub-national, national, and regional levels, comprehensive strategies are needed that are responsive to countries and regions with different burdens of violence.

These strategies are likely to blend targeted prevention to reduce the worst forms of violence with longer-term efforts to build more peaceful societies. Urgent action is needed to reduce conflict risk and to tackle violence hotspots in the most violent cities. This will lead to the fastest reductions in violence and provide new opportunities for development for those at risk of being left behind. At the same time, longer-term efforts are needed to transform harmful gender norms and to build societies that are safe for women, children, and young people to live in. Priorities 
must be set, but strategies should be integrated, recognizing that threats are interconnected; when done right, most effective solutions help prevent multiple types of violence (Cliffe and Steven, 2017).

The next two years provide opportunities to build a movement that is inspired by the potential of SDG16.1. In February 2019, the PyeongChang Global Peace Forum will issue a new global appeal for peace. The High-level Political Forum on Sustainable Development will meet at ministerial level in July to review SDG16. In September, the first SDG Summit will convene to "accelerate further actions to accelerate implementation" of parts of the 2030 Agenda (UN, 2015). This summit will be preceded by the International Day of Peace on 21 September. In 2020, a UN summit is planned. To seize these opportunities for SDG16.1, leadership will be needed from a coalition of champions, including governments, mayors, international organizations, civil society networks, foundations, and the private sector. 


\section{〈References〉}

Bellis, Mark A., Katie Hardcastle, Karen Hughes, Sara Wood, and Joanna Nurse. 2017. Preventing Violence, Promoting Peace - A Policy Toolkit for Preventing Interpersonal, Collective and Extremist Violence. Cardiff: The Commonwealth, available at https://www.thecommonwealth-healthhub.net/wp-content/uploads/ 2017/05/Preventing-Violence-Main-Report.pdf (accessed on November 19, 2018). Braga, Anthony A., and David L. Weisburd. 2012. "Pulling Levers: Focused Deterrence Strategies to Prevent Crime." No. 6 of Crime Prevention Research Review. Washington, D.C.: U.S. Department of Justice, Office of Community Oriented Policing Services.

Center on International Cooperation. "SDG Targets for Fostering Peaceful, Just and Inclusive Societies." Unpublished reports, available at http://cic.nyu. edu/sites/default/files/peaceful_just_inclusive_targets_ analysis_aug2016.pdf (accessed on November 19, 2018).

Cliffe, Sarah, and David Steven. 2017. “An Integrated Approach to Prevention - The Links between Prevention, the 2030 Agenda, and Sustaining Peace.” New York: Center on International Cooperation, available at http://cic.nyu.edu/ sites/default/files/cic_prevention_sdgs_sp_2017.pdf (accessed on November 19, 2018).

Diallo, Yacouba, Alex Etienne, and Farhad Mehran. 2013. "Global Child Labour Trends 2008 to 2012." Geneva: International Labour Organization, available at http://www.ilo.org/ipecinfo/product/download.do?type=document\&id=23015 (accessed on November 19, 2018).

Geneva Declaration on Armed Violence and Development. 2008. "Global Burden of Armed Violence 2008." Geneva: Geneva Declaration Secretariat, available at http://www.genevadeclaration.org/fileadmin/docs/Global-Burden-of-ArmedViolence-full-report.pdf (accessed on November 19, 2018).

Hillis, Susan, James Mercy, Adaugo Amobi, and Howard Kress. 2016. “Global Prevalence of Past year Violence against Children: A Systematic Review and Minimum Estimates." Pediatrics vol.137(3):e20154079, available at http://pediatrics.aappublications.org/content/pediatrics/137/3/e20154079.ful 1.pdf (accessed on November 19, 2018). 
Igarapé Institute. "Instinto de Vida" posted on Igarapé Institute website, available at https://igarape.org.br/en/issues/citizen-security/instinto-de-vida/ (accessed on November 19, 2018).

Know Violence in Childhood. 2017. "Ending Violence in Childhood. Global Report 2017." New Delhi: Know Violence in Childhood, available at http://globalreport.knowviolenceinchildhood.org/wp-content/uploads/2017 /09/Global-Report-2017.pdf (accessed on November 19, 2018).

Krisch, Maria, Manuel Eisner, Christopher Mikton, and Alexander Butchart. 2015. "Global Strategies to Reduce Violence by 50\% in 30 Years: Findings from the WHO and University of Cambridge Global Violence Reduction Conference 2014." Cambridge: University of Cambridge, available at http://www.vrc.crim.cam.ac.uk/VRCconferences/conference/violencereduc tionreport (accessed on November 19, 2018).

McEvoy, Claire, and Gergely Hideg. 2017. “Global Violent Deaths 2017 - Time to Decide." Geneva: Small Arms Survey, available at http://www. smallarmssurvey.org/fileadmin/docs/U-Reports/SAS-Report-GVD2017.pdf (accessed on November 19, 2018).

Muggah, Robert, and Nathalie Alvarado. 2016. "Latin America Could Cut Its Murder Rate By 50 Percent. Here’s How.” Americas Quarterly, October 4, 2016, available at http://americasquarterly.org/content/latin-americacould-cut-its-murder-rate-50-percent-heres-how\#.V_USdkO7WVV.twit ter (accessed on November 19, 2018).

OECD. 2015. "States of Fragility 2015: Meeting Post-2015 Ambitions." Paris: Organization for Economic Cooperation and Development, available at http://dx.doi.org/10.1787/9789264227699-en (accessed on November 19, 2018).

. 2016. "States of Fragility 2016: Understanding Violence." Paris: Organization for Economic Cooperation and Development, available at http://www.oecd.org/development/states-of-fragility-2016-978926426721 3-en.htm (accessed on November 19, 2018). 
2017. “Gender Equality and Women's Empowerment in Fragile and Conflict-Affected Situations: A Review of Donor Support." OECD Development Policy Paper (8). Paris: Organization for Economic Cooperation and Development Publishing, available at https://www.oecd. org/dac/conflict-fragility-resilience/docs/Gender_equality_in_fragile_situa tions_2017.pdf (accessed on November 19, 2018).

Office of the Special Representative of the Secretary-General for Children and Armed Conflict. "Annual Report: Children Faced with Unspeakable Violence in Conflict as Number of Grave Violations Increased in 2017," available at https://childrenandarmedconflict.un.org/children-faced-with - unspeakable-violence-in-conflict-as-number-of-grave-violations-incre ased-in-2017/ (accessed on November 19, 2018).

Open Government Partnership. 2018. "Empowering the People - Our Antidote to Authoritarianism." Opening Plenary at the Open Global Partnership (OGP) Global Summit on July 17, 2018, Georgia, available at https://www. opengovpartnership.org/stories/empowering-people-our-antidote-authorit arianism (accessed on November 19, 2018).

OSCE/ODIHR. 2009. Gender and Early Warning Systems: An Introduction. Warsaw: OSCE's Office for Democratic Institutions and Human Rights, available at https://www.osce.org/odihr/40269?download=true (accessed on November 19, 2018).

Pathfinders for Peaceful, Just and Inclusive Societies. 2017. "The Roadmap for Peaceful, Just and Inclusive Societies - A Call to Action to Change our World." New York: Center on International Cooperation, available at http://www.cic.nyu.edu/pathfinders (accessed on November 19, 2018).

Small Arms Survey. 2015. “The Global Burden of Armed Violence 2015: Every Body Counts database," available at http://www.genevadeclaration.org/ measurability/global-burden-of-armed-violence/global-burden-of-armed -violence-2015.html (accessed on November 19, 2018).

2016. "Monitoring Trends in Violent Deaths." Research Notes (59), available at http://www.smallarmssurvey.org/fileadmin/docs/ H-Research_Notes/SAS-Research-Note-59.pdf (accessed on November 19, 2018). 
The African Union Commission. 2015. “Agenda 2063 - The Africa We Want: A Shared Strategic Framework for Inclusive Growth and Sustainable Development - First Ten-year Implementation Plan 2014-2023.” Addis Ababa: The African Union Commission, available at http://www.un.org/ en/africa/osaa/pdf/au/agenda2063-first10yearimplementation.pdf (accessed on November 19, 2018).

UN. 2015. "Transforming Our World: The 2030 Agenda for Sustainable Development." New York: United Nations, available at https:// sustainable development.un.org/post2015/transformingourworld/publication （accessed on November 19, 2018).

_. 2017 "The Vision of the Secretary-General on Prevention,” 3 May 2017, available at https:/www.un.int/sites/www.un.int/files/Permanent\%20 Missions/ delegate/attachment_the_vision_of_the_sg_on_prevention.pdf (accessed on November 19, 2018).

_. 2018. "Peacebuilding and sustaining peace - Report of the SecretaryGeneral.” United Nations Document A/72/707-S/2018/43.

UN and World Bank. 2018. "Pathways for Peace: Inclusive Approaches to Preventing Violent Conflict.” Washington, D.C.: World Bank, available at https://openknowledge.worldbank.org/handle/10986/28337 (accessed on November 19, 2018).

UN Women. 2015. “A Framework to Underpin Action to Prevent Violence against Women." New York: United Nations Women, available at http://www.unwomen.org/en/digital-library/publications/2015/11/preventi on-framework\#view (accessed on November 19, 2018).

UNICEF. 2013. "Female Genital Mutilation/Cutting: A Statistical Overview and Exploration of the Dynamics of Change." New York: United Nations Children's Fund, availabe at http://www.unicef.org/publications/index_ 69875.html\# (accessed on November 19, 2018).

. 2014. “Ending Child Marriage: Progress and Prospects.” New York: United Nations Children's Fund, available at http://www.unicef.org/ media/files/Child_Marriage_Report_7_17_LR.pdf (accessed on November 19, 2018). 
UNHCR. "Global Trends Forced Displacement in 2017" posted on UNHCR the UN Refugee Agency website, available at http://www.unhcr.org/globaltrends 2017/(accessed on November 19, 2018).

Violence Prevention Alliance. "The Public Health Approach," available at http://www.who.int/violenceprevention/approach/public_health/en/ (accessed on November 19, 2018).

V-Dem Institute. 2018. “Democracy for all? V-Dem Annual Democracy Report 2018." Gothenburg: V-Dem Institute and University of Gothenburg, available at https://www.v-dem.net/media/filer_public/3f/19/3f19efc9-e25f-4356b159-b5c0ec894115/v-dem_democracy_report_2018.pdf (accessed on November 19, 2018).

Weisburd, David, David P Farrington, and Charlotte Gill (eds.). 2016. What Works in Crime Prevention and Rehabilitation - Lessons From Systematic Reviews. New York: Springer.

WHO. 2014. "Global Status Report On Violence Prevention 2014." Geneva: World Health Organization, available at http://apps.who.int/iris/bitstream/10665/ 145086/1/9789241564793_eng.pdf?ua=1\&ua=1 (accessed on November 19, 2018). 2015. "Preventing Youth Violence: An Overview of the Evidence." Geneva: World Health Organization, available at http://www.who.int/iris/bitstream/ 10665/181008/1/9789241509251_eng.pdf?ua=1\&ua=1\&ua=14625_eng.pdf\%3f ua=1 (accessed on November 19, 2018).

WHO, CDC, End Violence against Children, PAHO, PEPFAR, Together for Girls, UNICEF, UNODC, USAID, and World Bank. 2016. “INSPIRE - Seven Strategies for Ending Violence Against Children.” Geneva: World Health Organization, available at http://apps.who.int/iris/bitstream/10665/207717/1/ 9789241565356-eng.pdf?ua=1 (accessed on November 19, 2018).

WHO, London School of Hygiene \& Tropical Medicine, and South African Medical Research Council. 2013. “Global and Regional Estimates of Violence against Women: Prevalence and Health Effects of Intimate Partner Violence and Nonpartner Sexual Violence." Geneva: World Health Organization, available at http://apps.who.int/iris/bitstream/10665/85239/1/9789241564625_ eng.pdf?ua=1 (accessed on November 19, 2018). 
World Bank. 2011. "World Development Report 2011 - Conflict, Security and Development." Washington, D.C.: World Bank, available at http:// siteresources.worldbank.org/INTWDRS/Resources/WDR2011_Full_Text.p dfWDR 2011, box on human rights and conflict risk (accessed on November 19, 2018).

2018. “World Bank Annual Report 2018.” Washington, D.C.: World Bank. 